\title{
APLIKASI EKSPLORASI VIRTUAL MUSEUM NEGERI PROVINSI SULAWESI UTARA
}

\author{
Oktoverano Lengkong ${ }^{1}$ \\ Andria Wahyudi ${ }^{2}$ \\ Reynald G K Lumantouw ${ }^{3}$ \\ 1,2,3 Program Studi Sistem Informasi, Fakultas Ilmu Komputer Universitas Klabat, Manado \\ Universitas Klabat; Jl. Arnold Mononutu, Sulawesi Utara, Indonesia 95371 \\ Telp: 0431891035 Fax: 0431891036 ; www.unklab.ac.id \\ e-mail:1oktoverano@unklab.ac.id, \\ 2andriawahyudi@unklab.ac.id, \\ 3lumantouwr@yahoo.com.
}

Diterima: 3 Januari 2018/ Disetujui : 18 Januari 2018

\begin{abstract}
Information is important in adding insight and knowledge, if the information can be processed properly and can be delivered properly, then this information can be used as needed. By using technology support, information becomes easier to process and deliver. Virtual Tour, is a technology created to provide information in digital form. Virtual tour has been widely used to introduce a virtual building, but for museum building is rarely available even in North Sulawesi yet. North Sulawesi is part of eastern Indonesia with Manado as the capital has a museum that is the State Museum of North Sulawesi Province. Then the application is developed for the exploration of the State Museum of North Sulawesi province with features of first person view using Unity $3 D$ as a game engine and Google SketchUp as a 3D modeler. The development of this application uses the spiral model and the research methods used are observation and study literature. This application was created to attract visitors to come to the museum and hopefully this application can help visitors to find out more information of historic objects in the museum's main building.
\end{abstract}

Keywords: Virtual Tour, Museum of North Sulawesi Province, Unity 3D, Google SketchUp.

\begin{abstract}
ABSTRAK
Informasi merupakan hal penting dalam menambah wawasan dan pengetahuan, jika informasi tersebut dapat diolah dengan baik serta dapat disampaikan dengan baik, maka informasi ini dapat digunakan sesuai dengan kebutuhan. Dengan menggunakan dukungan teknologi, maka informasi menjadi lebih mudah diolah dan disampaikan. Virtual Tour, adalah sebuah teknologi yang diciptakan untuk memberikan informasi dalam bentuk digital. Virtual tour sudah banyak digunakan untuk memperkenalkan suatu bangunan secara virtual, namun untuk museum masih sedikit tersedia bahkan di Sulawesi Utara belum ada. Sulawesi Utara yang merupakan bagian di Indonesia timur dengan Manado sebagai ibukota, memiliki sebuah museum yaitu Museum Negeri Provinsi Sulawesi Utara. Maka untuk itu dikembangkan aplikasi eksplorasi Museum Negeri Provinsi Sulawesi Utara dengan fitur first person view menggunakan aplikasi Unity 3D sebagai game engine dan Google SketchUp sebagai 3D modeler. Pengembangan aplikasi ini menggunakan model spiral dan metode penelitian yang digunakan yaitu observasi dan study literature. Aplikasi ini dibuat untuk menarik minat pengunjung untuk datang ke museum dan diharapkan dapat membantu pengunjung untuk lebih mengetahui informasi objek bersejarah yang ada di dalam bangunan utama Museum Negeri Provinsi Sulawesi Utara.
\end{abstract}

Kata Kunci: Virtual Tour, Museum Negeri Provinsi Sulawesi Utara, Unity 3D, Google SketchUp 


\section{PENDAHULUAN}

Sulawesi Utara merupakan salah satu Kota di Indonesia timur dengan Manado sebagai ibukotanya, memiliki sebuah museum yaitu Museum Negeri Provinsi Sulawesi Utara. Berdasarkan observasi dan wawancara yang dilakukan peneliti di museum ini terdapat sekitar 2000 sampai 2500 peninggalan bersejarah Provinsi Sulawesi Utara sejak museum didirikan sampai saat ini. Objek bersejarah yang ada diperbaharui setiap 5 tahun. Gedung pameran di museum ini dibagi menjadi dua bagian yaitu gedung pameran tetap dan gedung pameran sementara. Gedung pameran sementara hanya dibuka jika ada acara khusus, sedangkan gedung pameran tetap adalah gedung utama yang menjadi tempat peletakkan objek-objek bersejerah di Sulawesi Utara. Di gedung pameran tetap memiliki 2 lantai, dengan total ruangan sebanyak 15 ruangan. Namun informasi untuk mengetahui ruangan sedang dikunjungi masih kurang jelas, karena ada beberapa ruangan yang tidak memiliki papan nama, dan tidak ada penjelasan singkat mengenai apa saja benda-benda peninggalan yang ada di dalam ruangan tersebut.

Secara etimologis, kata "Museum" diambil dari bahasa Yunani Klasik, yaitu: " Muze " kumpulan sembilan dewi yang berarti lambang ilmu dan kesenian [1]. Museum menurut International Council of museum (ICOM) adalah sebuah lembaga yang bersifat tetap, tidak mencari keuntungan, melayani masyarakat dan perkembangannya, dan juga terbuka untuk umum.[2].

Berdasarkan uraian di atas, maka pengertian museum adalah sebagai tempat menyimpan bendabenda kuno yang dapat digunakan untuk menambah wawasan dan juga sebagai tempat rekreasi. Seiring dengan berkembangnya zaman, museum memiliki makna yang sangat luas sesuai dengan pemikiran setiap individu maupun institusi.

\subsection{Multimedia}

Multimedia adalah kombinasi dari teks, seni, suara, animasi, dan video yang disampaikan oleh komputer atau alat elektronik [10]. Istilah yang lebih spesifik tentang digital mulitimedia memiliki pengertian komputer yang dapat dikontrol, terintegrasi dengan teks dan grafis serta mengandung suara, pergerakan gambar atau animasi yang dapat direpresentasikan atau ditransmisikan secara digital [11]. Multimedia memiliki beberapa elemen. Elemen-elemen yang termasuk di dalamnya adalah teks, suara, grafis, animasi, dan video [12].

\subsection{Grafika Komputer}

Grafika komputer atau computer graphics adalah bagian dari ilmu komputer yang berkaitan dengan pembuatan dan manipulasi gambar (visual)secara digital. Secara sederhana grafika computer bisa dikatakan grafika komputer 2D yang kemudian berkembang menjadi grafika komputer 3D, pemroses atas citra (image processing), dan pengelanan pola (pattern recognition). Grafika komputer sering dikenal juga dengan istilah visualisasi data [3].

Pola penggambaran yang paling sederhana adalah dengan menggunakan titik pada teknologi garis. Algoritma line Equation merupakan salah satu metode untuk menentukan lokasi koordinat titik pada teknologi garis dalam grafika komputer dengan cara menentukan nilai gradian garis serta garis yang berpotongan dengan sumbu $\mathrm{Y}$, sehingga bisa mengetahui pixel yang akan menyala pada screen coordinate [3].

\subsection{3-Dimensi (3D)}

3D adalah sebuah objek yang memiliki panjang, lebar, dan tinggi yang memilki bentuk. 3D tidak hanya digunakan dalam matematika dan fisika saja melainkan pada bidang grafis, seni, animasi, komputer dan lain-lain. 3D dapat menggambarkan setiap objek yang terjadi pada tiga sumbu sistem 
koordinat cartesian. Sebuah sistem koordinat Cartesian pada dasarnya adalah cara mudah menggambarkan sumbu $\mathrm{X}$ dan $\mathrm{Y}$. Dalam dunia 2D terdapat dua sumbu, $\mathrm{X}$ untuk sumbu horizontal dan Y untuk sumbuh vertikal, hal yang sama juga terdapat dalam dunia 3D, yaitu memiliki sumbu untuk koordinat yang akan digambar, tetapi dengan satu pengecualian, ada sumbu ketiga yaitu sumbu Z, yang mewakili kedalaman[4].
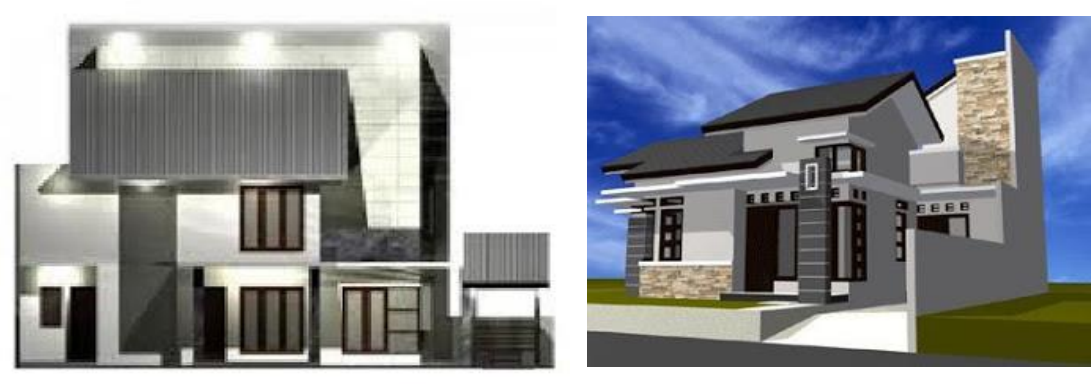

Gambar 1 Perbedaan gambar 2D dan 3D

Pada gambar 2.1 bisa dilihat perbedaan antara gambar 2D (kiri) dan gambar 3D (kanan), pada gambar 2D dapat dilihat gambar tersebut hanya terdiri dari dua sumbu, yaitu sumbu $\mathrm{X}$ untuk lebar, dan sumbu Y untuk tinggi. Sedangkan pada gambar 3D juga memiliki ruang seperti lemari. Istilah “3D” juga digunakan untuk menunjukkan represenntasi dalam grafika komptuer (digital), penggunaan 3D dalam grafika komputer dapat dipandukan dengan gambar 2D sebagai tekstur dari objek 3D yang dibuat[4].

\subsection{Google SketchUp}

Dengan menggunakan Google Sketchup dapat memudahkan peneliti dalam proses pemodelan pembuatan objek 3-Dimensi bangunan di dalam lingkungan museum negeri provinsi Sulawesi Utara.. Google sketchup adalah program modeling 3D yang dirancang untuk para arsitek, teknik sipil, pembuat film dan gambar, serta para professional. Sketchup merupakan sebuah program grafis yang diproduksi oleh Google. Program ini memberikan hasil utama yang berupa gambar sketsa 3 Dimensi. Sesuai namanya, perangkat lunak ini lebih mudah untuk digunakan dalam perancangan bangunan dan memiliki objek 3-Dimensi dengan perbandingan panjang, lebar, dan tinggi. Pengeditannya lebih mudah dibandingkan bila menggunakan perangkat lunak 3D modelling lain yang dalam pembuatannya mungkin butuh waktu yang lebih lama. Perangkat lunak Sketchup cukup fleksibel karena dapat membaca data format *.dxf dari file AutoCAD. *.3ds dari 3Dstudio Max, *bmp, *jpg, dan *.png, selain itu file yang dikerjakan di Sketchup juga dapat dengan mudah diekspor ke berbagai format tersebut[5].

\subsection{Game Engine}

Game engine merupakan tools untuk pembuatan sebuah game, game engine 3D tidak hanya digunakan untuk membuat game, game engine ini juga memiliki kemampuan untuk menggambarkan sebuah lingkungan virtual dalam keadaan real-time dan realistis. Sehingga cocok jika aplikasi virtual eksplorasi RSUP Prof Dr. R. D. Kandou Manado ini menggunakan game engine.

Game engine adalah sebuah perangkat lunak yang dirancang untuk menciptakan dan mengembangkan sebuah game. Game engine mempunyai developmenttools dengan tampilan visual dan langsung terintegrasi sehingga tools-tools tersebut dapat digunakan kembali untuk mengembangkan game lain. Dengan menggunakan game engine, maka pengembangan game akan 
menjadi lebih cepat, serta mengurangi biaya dan tingkat kerumitan. Contoh game engine yang cukup terkenal adalah game engine Unity 3D[6].

Sebuah game engine memiliki beberapa komponen utama. Secara garis besar komponenkomponen game engine terbagi menjadi 4 bagian, yaitu:

\section{a. Grafik rendering}

Rendering merupakan fitur utama dari game engine sehingga mampu menampilkan model baik dalam 2 dimensi ataupun 3 dimensi. Grafik rendering membaca objek yang di-input, lalu menampilkan setiap pixeldari objek tersebut pada layar.

\section{b. Physic Game}

Game engine memungkinkan untuk menentukan apa yang terjadi pada objek dan mensimulasikan efek yang terjadi pada objek sesuai dengan karakteristik objek tersebut. Efek-efek tersebut bisa berupa: pecah, retak, memantul dan sebagainya.

\section{c. Platfrom abstraction}

Platform abstraction mempermudah untuk mengembangkan engine di setiap platform yang berbeda. Hal ini ditujukan agar pengembang game tidak harus merombak ulang kode program jika ingin mengembangkan game yang sama ke platform yang berbeda.

\section{d. Integrated Development Environment}

Game engine menyederhanakan dan memudahkan proses pengembangan game seperti koding, penambahan efek visual dan suara, memasukkan AI, collision detection, fasilitas jaringan dan sebagainya.

\subsection{Unity $3 D$}

Peneliti menggunakan Unity 3D sebagai tools dalam membuat aplikasi ini, dikarenakan Unity 3D dapat memudahkan peneliti untuk memasukkan pemodelan yang sudah dibuat melalui Google SketchUp. Hal itu dikarenakanUnity editor melayani sebagai integrated development environtment (IDE) dengan panel untuk project, scripts dan object yang dapat disesuaikan dengan kebutuhan pengembangan aplikasi [13].

Unity 3D merupakan game engine yang ditargetkan pada independent developers dan memungkinkan untuk rapid testing of ideas. Unity menyediakan penggambungan yang kuat antara graphics, audio, dan physics[7]. Unity 3D merupakan game engine yang sering digunakan oleh pemula dan developer, dimana game engine ini dapat bekerja dengan 3D modeling, run quickly, mendukung beberapa bahasa pemograman seperti bahasa C, UnityScript yaitu dalam bentuk JavaScript. Game yang dihasilkan dengan menggunakan Unity 3D dapat mendukung beberapa platform seperti iOS, Android, Windows dan Linux.

\subsection{Bahasa Pemograman}

Bahasa pemrograman merupakan bahasa yang berisi kumpulan kode yang dirancang untuk mengkomunikasikan instruksi kepada mesin, terutama pada komputer. Bahasa pemrograman digunakan untuk perancangan perangkat lunak pada komputer. Bahasa pemrograman berorientasi objek digunakan untuk mentranslasikan classes, attributes, operations dan messages ke dalam bentuk yang dapat dieksekusi oleh sebuah mesin. Bahasa pemograman yang digunakan oleh peneliti pada aplikasi yang dibuat adalah $\mathrm{C \#}$. 


\subsubsection{C\#}

C\# (C sharp) adalah bahasa pemrograman yang sederhana dan modern untuk berbagai kepentingan. $\mathrm{C \#}$ adalah yang dikembangkan dari bahasa $\mathrm{C}$, bahasa yang merupakan salah satu bahasar pemograman dasar pada ilmu komputer. Bahasa $\mathrm{C \#}$ merupakan salah satu bahasa pemrograman yang berorientasi objek [8].

\subsubsection{Javascript}

Javascript merupakan prototype-base scripting language. Bersifat dinamis dan multifungsi. Bahasa ini banyak diimplementasi pada web. Bahasa ini memiliki banyak syntax yang dipengaruhi oleh bahasa C. Bahasa javascript sering dikombinasikan dengan bahasa pemrograman lain yang bertujuan untuk membuat aplikasi yang lebih interaktif. Salah satu kombinasi yang populer adalah HTML5 dan javascript. Kombinasi ini dibuat untuk membuat web interaktif. Selain itu, kombinasi dengan javascript sering digunakan dalam pengembangan game computer[8].

Berdasarkan latar belakang diatas Gedung Museum Negri Provinsi Sulwesi Utara ini, cukup besar, sehingga dibutuhkan informasi yang lengkap dan jelas. Dalam hal ini informasi ruangan seperti tata letak atau posisi, atau informasi lainnya seperti informasi dari isi ruangan, benda-benda bersejarah apa yang ada di dalamnya. Dari hasil pengamatan oleh peneliti di dalam gedung pameran tetap, peneliti berkeinginan untuk merancang sebuah aplikasi eksplorasi virtual dengan fitur first person view menggunakan game engine yang menampilkan informasi dari setiap ruangan yang ada di dalam gedung pameran tetap, dan juga membantu pengunjung dalam hal pengalamannya melakukan eksplorasi di dalam gedung pameran tetap Museum Negeri Provinsi Sulawesi Utara.

\section{METODE PENELITIAN}

\subsection{Metode Pengembangan}

Dalam penelitian ini peneliti menggunakan proses model spiral. Model ini merupakan proses model yang menggabungkan pendekatan prototyping yang bersifat iteratif dan waterfall yang bersifat sistematis [9]. Dengan menggunakan proses model ini memungkinkan peneliti untuk melakukan proses yang iterative atau berulang tetapi dengan tahap yang lebih berkembangan dari proses yang telah dilewati sebelumnya, sehingga peneliti dapat memahami dan mempelajari resiko yang ada dan dapat menangangi resiko tersebut. Gambar 2 memperlihatkan tahapan proses model ini.

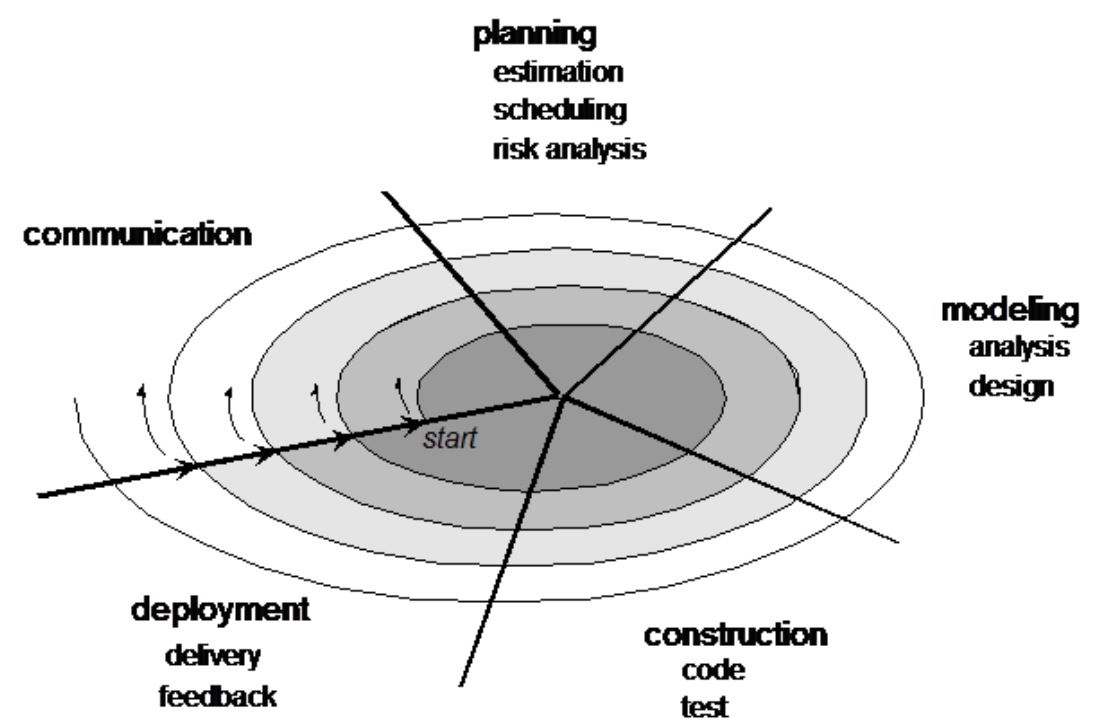

Gambar 2 Tahapan Proses Model Spiral 


\section{HASIL DAN PEMBAHASAN}

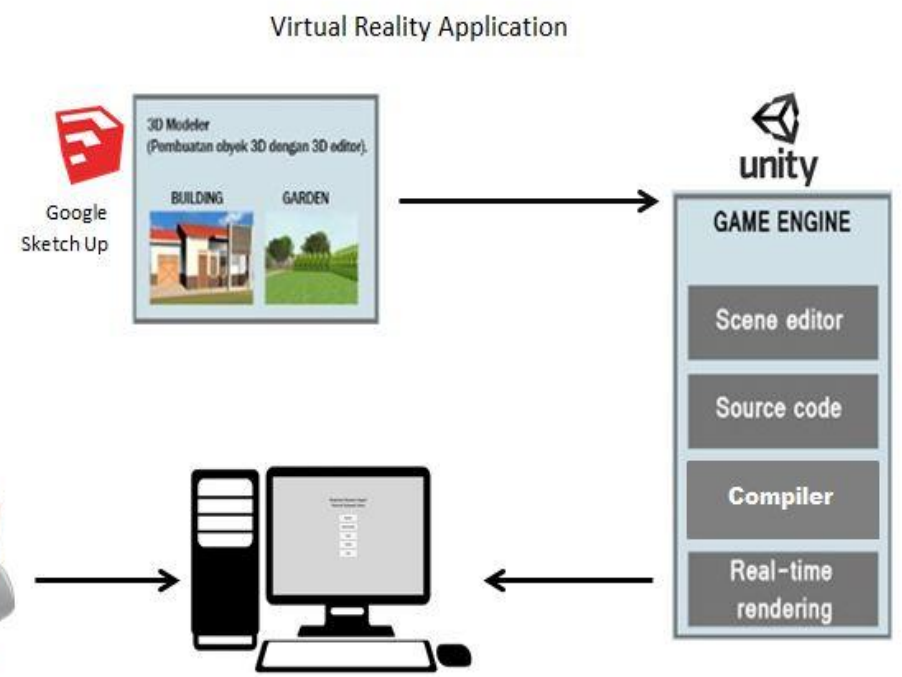

Gambar 3 Kerangka Konseptual Aplikasi

\subsection{Pembahasan}

Gambar 3 Memperlihatkan kerangka konseptual aplikasi dan gambaran secara umum dari aplikasi, dapat dideskripsikan sebagai berikut :

1. Pembuatan objek dan bangunan 3D menggunakan Google Sketchup. Peneliti membuat objek 3D gedung pameran utama yang ada di Museum Negeri Provinsi Sulawesi Utara dengan menggunakan aplikasi Google SketchUp. Proses yang kedua adalah pembuatan aplikasi virtual eksplorasi menggunakan game engine Unity 3D dengan memanfaatkan hasil dari pembuatan 3D models dalam proses sebelumnya. Hasil dari pembuatan 3D models tersebut dimasukkan ke dalam game engine Unity 3D.

2. Pembuatan aplikasi menggunakan game engine.Dalam game engine ini dilakukan empat tahap yaitu, scene editing, source code, compiler, rendering. Dalam Unity 3D ini juga dibuat interface dari aplikasi yang memiliki menu utama yaitu, eksplorasi, denah bangunan, info aplikasi, bantuan, keluar. Beserta fungsi-fungsi yang ada dalam aplikasi, yaitu select start point, select end point, select navigation, get info, move forward, move backward, turn left, dan turn right. Aplikasi yang sudah dibuat menggunakan game engine Unity3D ini menghasilkan executable file untuk di jalankan di komputer

3. Aplikasi berbasis desktop. Pengguna dapat langsung menggunakan aplikasi di komputer.

\subsection{Hasil}

Berikut merupakan hasil dari aplikasi eksplorasi virtual Museum Negeri Provinsi Sulawesi Utara. 


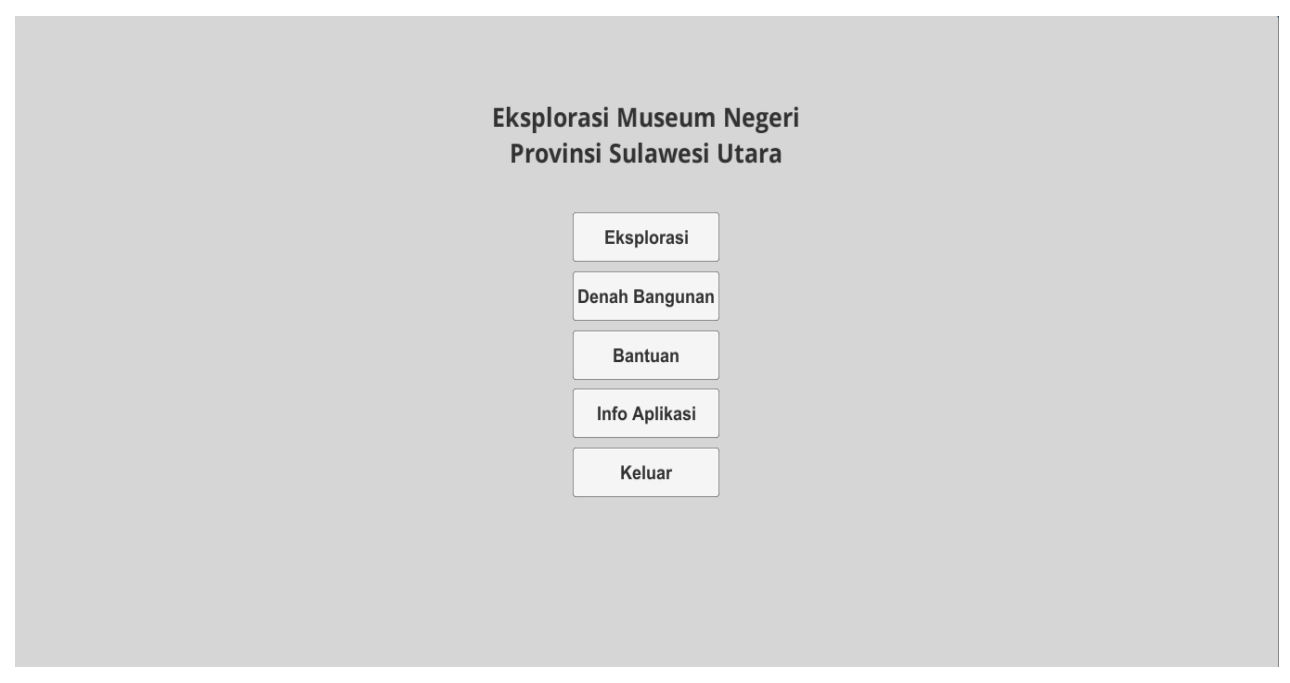

Gambar 4. Menu utama Aplikasi

Gambar 4 adalah tampilan menu utama aplikasi. Pada menu ini terdapat 5 pilihan button, yakni button eksplorasi untuk menjelajahi gedung pameran tetap museuem, button denah bangunan untuk melihat bangunan-bangunan yang ada di lingkungan museum, button bantuan untuk panduan saat akan menjelajahi gedung pameran tetap, button info aplikasi yang berisi info dari aplikasi,button keluar untuk keluar dari aplikasi.

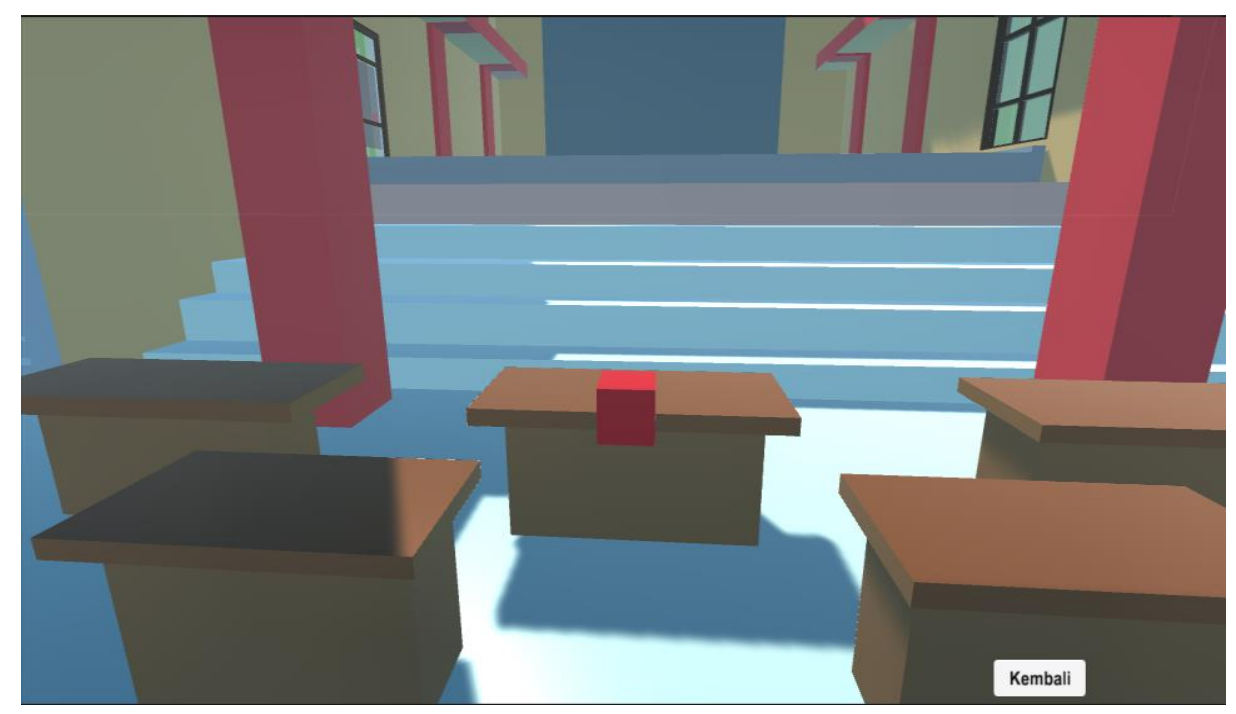

Gambar 5. Tampilan Saat Eksplorasi

Gambar 5 merupakan tampilan saat memilih menu eksplorasi yang akan membawa kita menjelajahi gedung pameran tetap. Eksplorasi pada aplikasi ini dibatasi hanya di dalam gedung pameran tetap. 


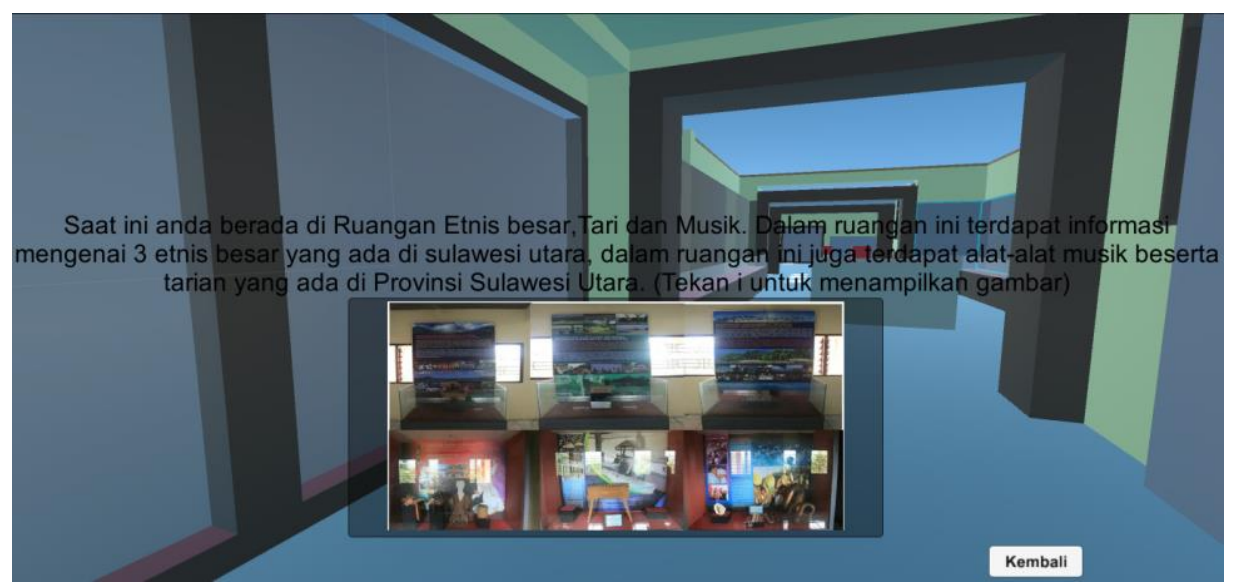

\section{Gambar 6 Tampilan informasi}

Gambar 6 merupakan tampilan informasi yang akan keluar saat melakukan eksplorasi di dalam gedung pameran tetap Museum Negeri Provinsi Sulawesi Utara. Informasi berupa teks dan gambar foto.

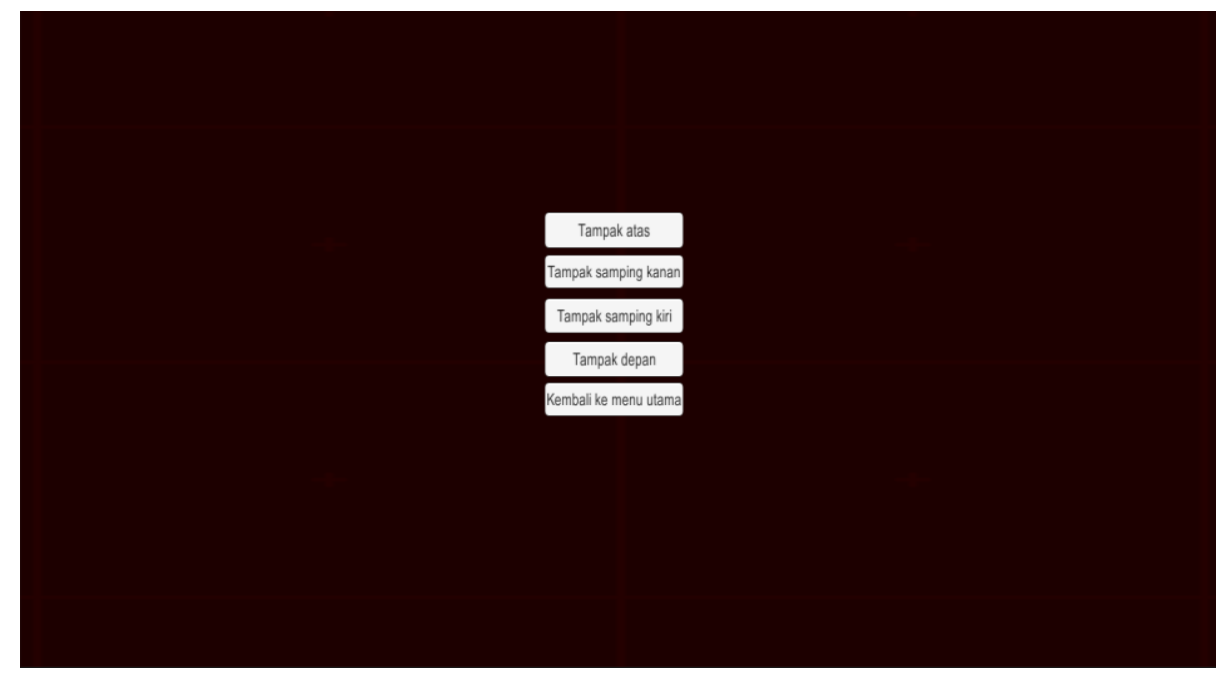

Gambar 7 Tampilan Menu Denah Bangunan

Pada gambar 7 adalah tampilan menu jika pada menu utama user memilih menu Denah Banguan dalam menu ini terdapat 4 button untuk memilih view yang sudah tersedia. Dimana user dapat memilih mode untuk meilhat tampilan tampak dari atas, tampak samping kanan, kiri, dan juga bagian depan atau muka. 


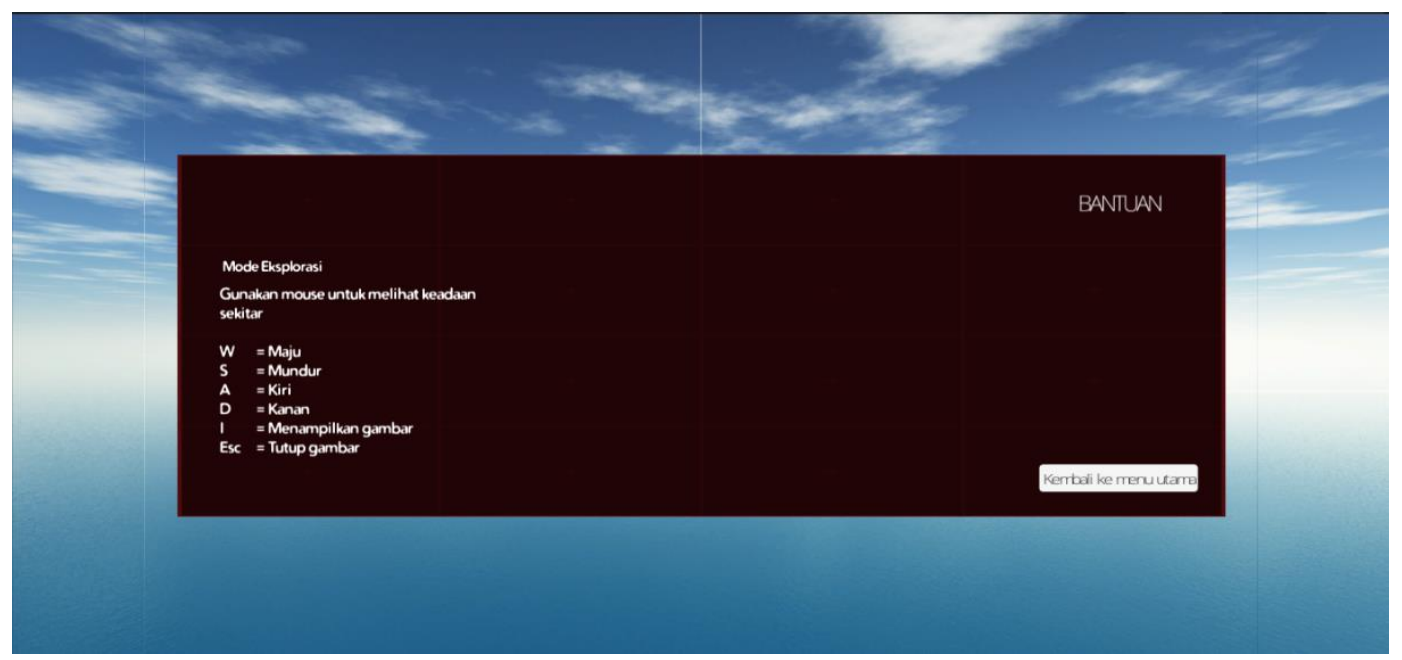

Gambar 8 Tampilan Menu Bantuan

Gambar 8 adalah tampilan dari menu Bantuan, di dalamnya terdapat petunjuk untuk menggunakan aplikasi. Tombol - tombol apa yang harus digunakan untuk melakukan eksplorasi, beserta penggunaan mouse sebagai navigasi.

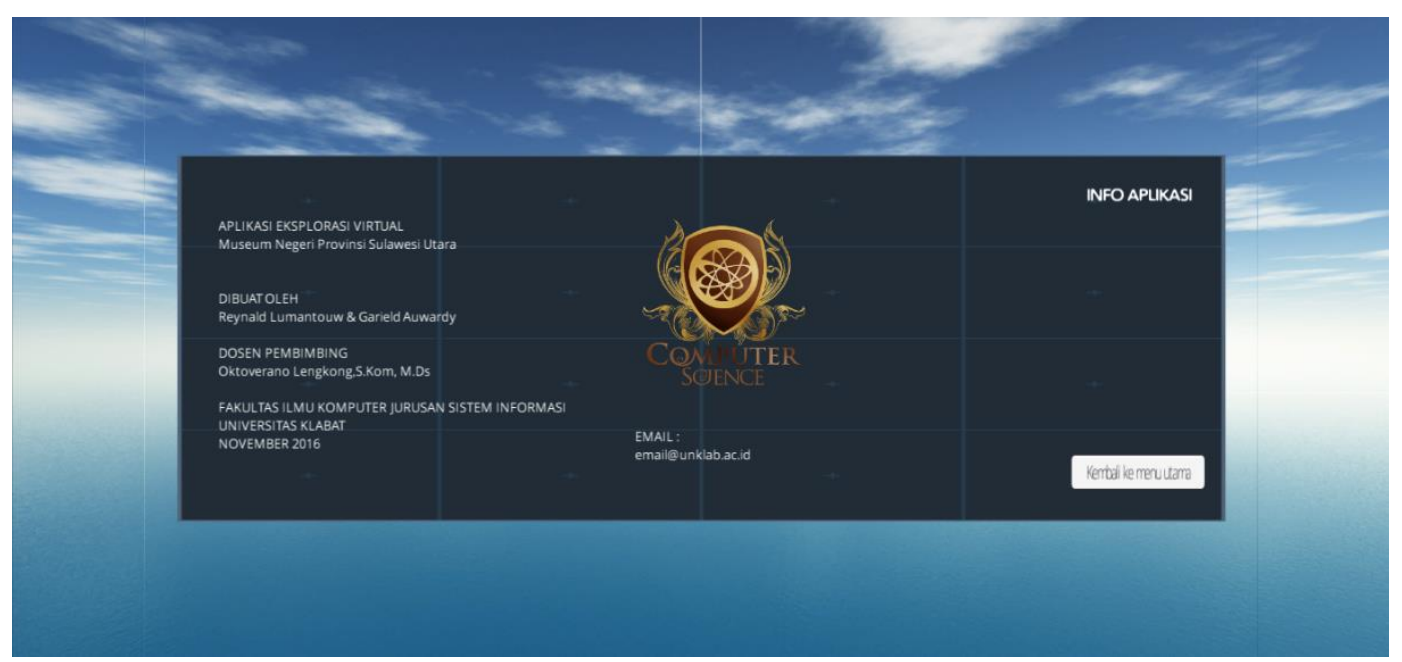

Gambar 9 Tampilan Menu Info Aplikasi

Gambar 9 adalah tampilan dari menu Info Aplikasi di dalamnya terdapat informasi singkat mengenai aplikasi dan juga profil dari pembuat aplikasi eksplorasi Museum Negeri Provinsi Sulawesi Utara.

\section{KESIMPULAN}

Berdasarkan penelitian yang sudah dilakukan, maka dapat disimpulkan sebagai berikut :

1. Aplikasi Eksplorasi Virtual Museum Negeri Provinsi Sulawesi Utara dengan fitur First Person View menggunakan Game Engine berjalan pada PC dengan sistem operasi Windows 8

2. Aplikasi ini dibuat dengan menggunakan Google SketchUp dan game engine Unity $3 D$

3. Aplikasi memberikan informasi mengenai isi dari ruangan yang ada di dalam museum

4. Aplikasi memberikan pilihan untuk melihat view lingkungan sekitar museum. 


\section{SARAN}

Pada penelitian ini peneliti masih perlu adanya penyempurnaan pada aplikasi sehingga peneliti memberikan saran untuk pengembang selanjutnya dari penelitian ini yaitu:

1. Penambahan tekstur bangunan museum secara detail.

2. Penambahan fitur eksplorasi di luar gedung utama museum.

3. Pengembangan aplikasi untuk versi mobile.

4. Penambahan benda-benda bersejarah dalam model 3D.

\section{DAFTAR PUSTAKA}

[1] A. Akbar, 2010, Museum di Indonesia Kendala dan Harapan, Papas Sinar Sinanti, Jakarta

[2] S. Styliani, 2009, "Virtual Museum, A Survey and Some Issues for Consideration." Journal of Cultural Heritage [online], 10(4), pp. 520-528. Available: http://lib.unnes.ac.id/20896/1/5302410066-S.pdf [Dec. 14, 2015].

[3] Mufadhol dan M. S, Suprayogi, "Penetuan koordinat titik pada teknologi garis dalam grafika komputer dengan menggunakan algoritma line equation" vol. 12, Jul. 2014.

[4] P. Sulistyorini, "Pemodelan Visual dengan Menggunakan UML dan Rational Rose," Dinamik Jurnal Teknologi Informasi, vol. 14.1, 2009.

[5] M. Gargenta, Learning Android Building Applications for the Android Market, USA: O'Reilly Media, 2011.

[6] S. Jabonir, W. Hermanto and C. Wongso, "Aplikasi Game Simulasi 3D "Binusian Life" Berbasis OGR3D Graphics Engine," Binus University, Bandung, 2011.

[7] F. Winkler and C. Barret, "Computer Games : Introduction to the Unity3D (vers. 3.4)," Purdue University, 2011.

[8] P. Sulistyorini, "Pemodelan Visual dengan Menggunakan UML dan Rational Rose," Dinamik Jurnal Teknologi Informasi, vol. 14.1, 2009.

[9] R.Pressman. Software Engineering: A Practitioner's Approach. New York: McGraw-Hill, 2010, pp.13-14.

[10] M. Pagani, 2005, Encylclopedia of Multimedia Technology and Networking, Idea Group Publishing, Italy

[11] I. Binanto, 2010, Multimedia Digital - Dasar Teori dan Pengembangannya, Andi Offset, Yogyakarta.

[12] G. P. Koapaha, dan T. A. Winata,, 2015, Aplikasi Navigasi Denah 3D Pada Rumah Sakit Umum Daerah Bitung Menggunakan Game Engine Berbasis Android, skripsi, Fakultas Ilmu Komputer, Universitas Klabat, Airmadidi Manado

[13] R. Sael, 2013, Aplikasi Virtual Reality Eksplorasi Kampus Universitas Klabat Menggunakan Game Engine, Skripsi, Universitas Klabat, Airmadidi, Manado. 